\title{
北海道における鮮新一洪積世の火山活動の時代
}

\author{
湊 正 雄・橋 本 誠二・藤 原 嘉 樹·熊 野 純 男1

\section{Volcanic Activities of the Pliocene and Pleistocene in Hokkaido}

\author{
M. Minato, S. Hashimoto, Y. Fujiwara and S. Kumano
}

私ぞもは，北海道に発達する第四系についていささか 研究を進めている。、いのところ踏査地は限られてお り，第四系の下底の認定のためには，鮮新統についても 検討を余儀なくされるなどの事情にあって，全般的なこ とを述べ得るのは，な添，かなり将来のことに属してい る.作業は私ども 4 名がどの分野についても協力して行 なってきたししかし，岡田昭明・五十嵐八枝子・高橋輝 明・渡辺シルビヤ・太田茂志氏らを始め, 他の数名の大 学院生には, 野外調査や内業の一部について協力しても らっている. 結果については，それらの方々と共に遂次 報告の予定でいるので参照ねがいたい.

北海道の 鮮新一洪積世前半にわたる火山活動の 経緯 は, この研究の過程で少しら゙つ明らかにされたものであ る. いまのところ, 氷期(Günz) 以降については, 支篎・ 洞爺・クッタラウシのカルデラ周辺で, 火山噴出物の層 序関係が編をれている. Matuyama/Brunhes 期および Jaramillo 事件の前後にかけては, 旭川丘陵, 美瑛, 新 得, 佐幌岳周辺で, 火山噴出物の層序が樹立されている.

Olduvai 事件から Gauss/Matuyama 期にかけては, 幕別, 足寄地方, 鮮新世の大半注本別・足寄にかけての 火山噴出物の対比が進められている.

踏查はこのほかに増毛山塊・更別原野・根釧原野およ び札幌周辺にわたっており, 鮮新世初葉から現世にわた っている. 火山活動の時期について, 標準的な層序表 は, いち㧍う出来あがったことになる.ここでは首題に 沿い, 鮮新世と洪積世の前半について, 私どもの現在の 結論を要約しておく.

1) 鮮新世初期 $\left(5.50 \times 10^{6}\right.$ Y. B. P. 前後) に Basalt の溶岩流・集塊岩

2）本別層群の上部，稲牛夾夾層に前後する（恐らく $5.00 \times 10^{6}$ Y. B. P. 前後) Rhyolite 質軽石流

3) Matuyama 逆帯磁期初葉（恐らく 2.40 2.10× $10^{6}$ Y. B. P 前後) の Basalt の溶岩流, 脉岩

4) Olduvai 事件前後 $\left(2.10 \sim 2.00 \times 10^{6}\right.$ Y. B.P) の
Rhyolite 質軽石流

5) Jaramillo 事件頃 $\left(0.95 \sim 0.90 \times 10^{6}\right.$ Y. B.P $)$ の Rhyolite 質軽石流

6) Jaramillo 事件以後 Matuyama/Brunhes 境界以 前の頃の Dacite 質軽石流

7) Brunhes 正带磁期初葉の Rhyolite 質軽石流とい ったものは，層位上，良好な鍵となっている。

以上のうち 1) 注本別層最下部に認められるものであ る.2）汒ムラウシ溶結凝灰岩と呼ばれてきたもので ある. しかし石北峠, 湧別川, 幌加湧別, パンケニコロ 溶結凝灰岩などと称されてきたものも，この層準にくる 可能性がある. 3) 滰川・愛別・上川・旭岳・白滝・ 丸瀬布・北見富士・常元・小利別・足寄太などに, 溶岩 流あるい注脉岩として広く分布している，4）は池田層 の下部に認められるるので，分布は限られている．5） も同様に分布は広くないが，佐幌岳西南方に存在するも ので鍵層としては共に重要なものである，6）の分布は かなり広く，上川: 大雪山・上支湧別・十勝川上流・石 狩岳・北見富士・常元・小利別に分布しているらしく思 はれる・標式的なものは佐幌岳付近・パンケニコロ川に みられる・7）注従来, 富良野・安足間・十勝溶結凝灰 岩, あるいは幾寅凝灰岩などと呼ばれてきたもので分布 は広い。

以上のような，重要な示準者を鍵として対比を進めて みると，2）と3）の間, 恐らくは Gilbert 逆帯磁期の 上半と考光られるところに，広く Dacite ないし Basaltic andesite 質の溶岩流や集塊岩が認如る。また 4）と5）の間にも各地に Andesite 質溶岩流や脈岩・集 塊岩が発達している.

上記の火山岩のうち, Rhyolite 質軽石流の噴出源は, いずれも日高帯の延長部にあつたとみられることは重要 な知見である。

Olduvai 事件を鮮新一洪積世の境界のいちおうの目安 として採用するならば, 池田層下部なるものは, 鮮新統

\footnotetext{
1) 北海道大学
} 


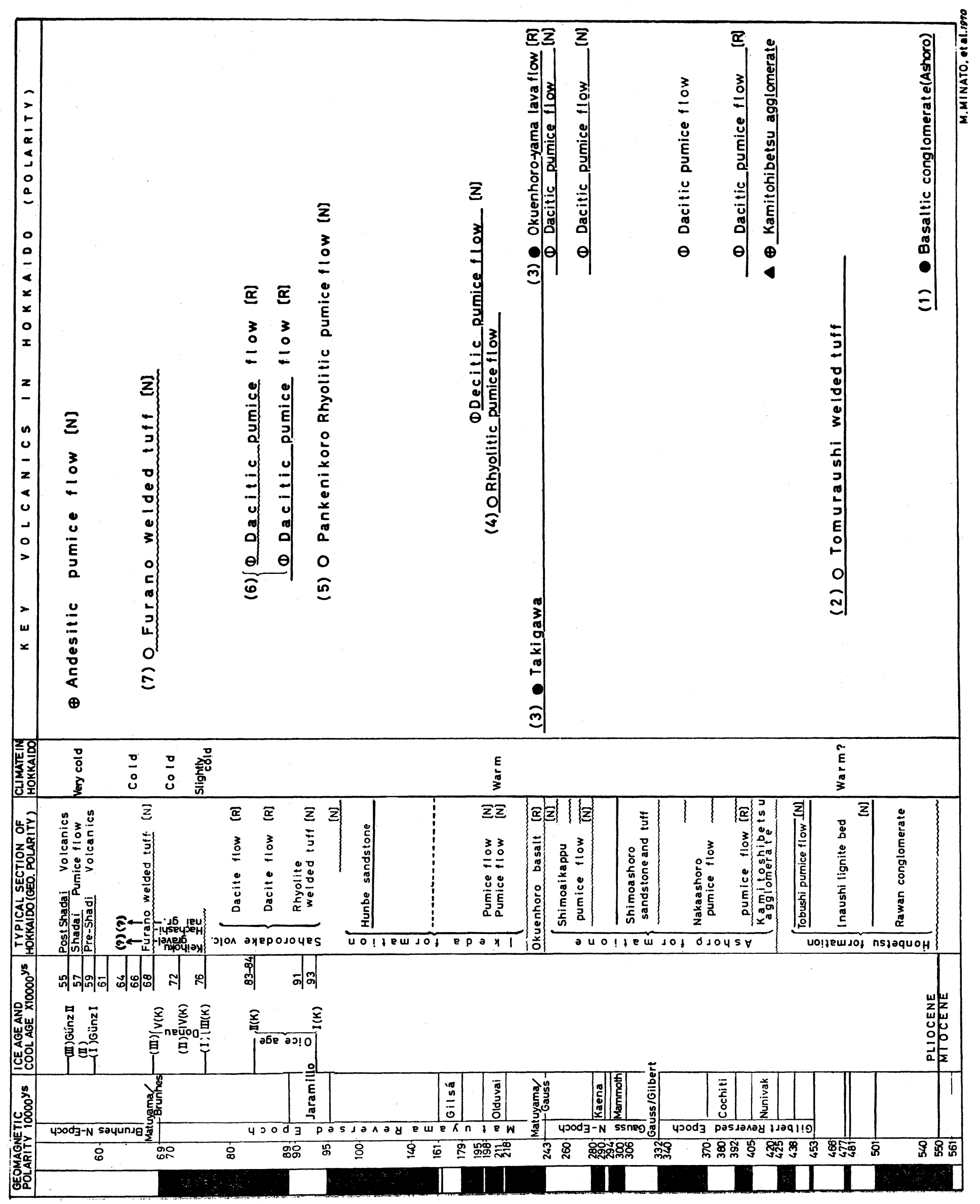


最上部から洪積統最下部にわたる地層とみなされるにい たった・これも重要な知見である。これと同様なことは， 別の立場からすでに述べられたことがある７）の軽石 流の層準に前後して, 各地で厚い砂磪層が認められる. 恵北層, 名寄の初茶志内層などはその例である. 花粉分 析から推定すると, こ礼らの砂磂層の堆積当時は, やや 寒冷で現在に比べて 緯度差にして 1 3․ も気候帯がず 机ていたことになる。こ秃に対して氷期に刘比される層
準は，いずれもこれらの砂䃯層の上位に認められる，気 候帯は緯度差にして 5 $6^{\circ}$ 以上にもおよびきわめて 寒 冷であったことは疑うことはできない，たとえば，社台 軽石流の直上の層準はその好例の一つである. これは Günz 水期に対比されるものと私どもは考えている. 火山活動の諸問題について, 石川俊夫 ·舟橋三男教授 からは折にふれて示唆に富んだ御教示を乔うしてきた。 ここに深い感謝の意を表する次第である. 